\title{
Perbedaan umpan dan waktu pengoperasian pancing dasar terhadap hasil tangkapan di Teluk Manado
}

\author{
Different baits and operation times on the fish catches of bottom hand line in Manado Bay
}

\author{
FEBRYK S. MANANOHAS*, ALFRET LUASUNAUNG, LEFRAND MANOPPO, JOHNNY BUDIMAN, dan \\ LUSIA MANU
}

Program Studi Pemanfaatan Sumberdaya Perikanan, Fakultas Perikanan Dan Ilmu Kelautan, universitas sam ratulangi, manado 95115

\begin{abstract}
One of the important economic resources of North Sulawesi waters is demersal fish, such as deep sea red snapper. These fish live around the bottom with complex topography, so that not all fishing gears can be operated in that area, except bottom hand line. This fishing gear has been widely used by coastal communities in North Sulawesi to catch demersal fishes, since it is simple, cheap, and easy to manage with a small boat. Although the gear's design has evolved over centuries, there is still potential to develop for environmental safety and sustainability. The objective of this research was to study the effect of different baits and operation times on the fish catch and identify the fish species. This research was done in Manado Bay waters, North Sulawesi, on July to October 2018, using an experimental method. The baits were mackerel fish (Decapterus sp), frigate tuna (Auxis rochii), squid (Loligo sp), and anchovies (Stolephorus sp). This fishing gear was operated in the morning and afternoon. The study applied randomized block design. Results found 67 fish consisting of 5 species. ANOVA showed that bait types gave significant effect on the fish catch, but operation time did not significantly affect the catch. BNT test revealed that the use of mackerel bait did not give significantly different effect on fish catch from that of squid bait, but very significantly different effect on the fish catch from that of frigate tuna bait and anchovy bait.
\end{abstract}

Key words: Bottom hand line; demersal fish; bait type; operation time; Manado Bay

\begin{abstract}
ABSTRAK
Salah satu sumberdaya ekonomis penting perairan Sulawesi Utara adalah ikan demersal seperti kakap merah laut dalam. Jenis-jenis ikan ini hidup di dasar perairan dengan topografi yang kompleks, sehingga tidak semua alat tangkap dapat dioperasikan di daerah tersebut, kecuali alat tangkap pancing dasar. Pancing dasar merupakan salah satu alat tangkap yang umum digunakan oleh masyarakat nelayan untuk menangkap ikan demersal, karena konstruksinya sederhana, relatif murah dan mudah dioperasikan dengan kapal ukuran kecil. Walaupun alat tangkap ini telah berkembang sejak lama, tetapi efisiensi penangkapan ikan dan selektivitasnya masih memiliki potensi pengembangan untuk memenuhi kriteria ramah lingkungan dan berkelanjutan. Penelitian ini bertujuan untuk mempelajari pengharuh jenis umpan dan waktu operasi terhadap hasil tangkapan pancing dasar, dan mengidentifikasi jenis-jenis ikan yang tertangkap. Penelitian ini dikerjakan di perairan Teluk Manado pada bulan Juli - Oktober 2018, yang didasarkan pada metode eksperimental fishing. Umpan yang digunakan terdiri dari ikan layang (Decapterus sp), tongkol (Auxis rochii), cumi-cumi (Loligo $s p$ ), teri (Stolephorus sp) yang tersedia selama penelitian. Alat tangkap ini dioperasikan pada pagi hari dan sore hari. Penelitian ini menggunakan rancangan acak kelompok. Hasil tangkapan total sebanyak 67 ekor, yang terdiri dari 5 spesies ikan. Analisis sidik ragam menunjukan bahwa perbedaan jenis umpan pada pancing dasar memberikan pengaruh yang nyata terhadap hasil tangkapan. Tetapi perbedaan jam operasi tidak berpengaruh nyata terhadap hasil tangkapan. Hasil uji BNT untuk perlakuan menunjukkan bahwa penggunaan umpan layang tidak berbeda nyata dengan umpan cumi, tetapi berbeda sangat nyata dengan umpan tongkol dan umpan teri.
\end{abstract}

Kata-kata kunci: Pancing dasar; ikan demersal; jenis umpan; waktu operasi; Teluk Manado.

\footnotetext{
*Penulis untuk penyuratan; email: febrykmananohas88@gmail.com
} 


\section{PENDAHULUAN}

Perikanan demersal di Indonesia pada umumnya merupakan tipe perikanan multi spesies yang dieksploitasi dengan menggunakan berbagai alat tangkap atau multi gears. Hasil tangkapan ikan demersal biasanya terdiri dari berbagai jenis yang jumlah individunya tidak terlalu besar. Di perairan Laut Jawa misalnya, antara lain seperti kakap merah, Lutjanidae, manyung, Ariidae, gerot-gerot, Pomadasyidae, kurisi, Nemipteridae, beloso, Synodontidae, kuniran, Mullidae, layur, Trichiuridae, petek, Leiognathidae dan bawal putih, Stromateidae. (Suman, 2007).

Suatu issue di daerah, bahwa sebagian dari produksi ikan-ikan demersal laut dalam di perairan Sulawesi Utara, masih dihasilkan dengan cara-cara ilegal seperti penggunaan racun potasium sianida. Mengingat perairan di kawasan timur Indonesia hanya mempunyai paparan (continental shelf) relatif sempit, dengan dugaan stok ikan demersal yang tidak terlalu besar (Badrudin, 1998), maka pemanfaatan ikan demersal tersebut harus benarbenar mempertimbangkan daya dukung sumberdaya yang tersedia tanpa merusaknya dengan cara-cara ilegal. Daerah penangkapan ikan demersal pada kedalaman yang lebih dari 100 meter biasanya ditujukan untuk beberapa jenis kakap merah laut dalam seperti Pristipomoides spp, Etelis spp, dan Aprion spp (Ram, 1995). Oleh karena itu, pengembangan teknologi penangkapan ikan khususnya ikan-ikan demersal laut dalam, perlu lebih ditekankan pada alat tangkap ikan yang ramah lingkungan, dengan harapan dapat memanfaatkan sumberdaya perikanan demersal secara berkelanjutan.

Ikan-ikan demersal yang berukuran layak tangkap biasanya hidup di perairan yang lebih dalam, dengan topografi dasar laut yang kompleks, sehingga tidak semua alat tangkap dapat dioperasikan di daerah tersebut; dan hanya pancing dasar yang diketahui nelayan untuk menjangkau dan memanfaatkan sumberdaya demersal tersebut.

Menurut buku petunjuk teknis (http:/www.dkp.go.id., 2008), bahwa alat penangkap ikan yang ramah lingkungan memiliki kriteria sebagai berikut: selektivitas tinggi, hasil tangkapan sampingan rendah, tidak merusak lingkungan, tidak menangkap spesies yang dilindungi, pengoperasian alat tidak membahayakan nelayan, dan tidak beroperasi di daerah terlarang. Pancing dasar merupakan salah satu alat tangkap untuk ikan-ikan demersal, yang hampir memenuhi semua kriteria yang dipersyaratkan oleh petunjuk teknis tersebut.

Pancing dasar (bottom hand line) merupakan salah satu alat tangkap yang umum digunakan oleh masyarakat nelayan untuk menangkap ikan-ikan demersal, karena konstruksinya sederhana, relatif murah dan mudah dioperasikan dengan kapal atau perahu ukuran kecil. Walaupun prinsip dasar alat tangkap pancing telah berkembang sejak lama, tetapi efisiensi penangkapan ikan dan selektivitasnya masih memiliki potensi pengembangan untuk memenuhi kriteria ramah lingkungan dan berkelanjutan. Penelitian ini bertujuan untuk mempelajari pengaruh beberapa jenis umpan dan waktu operasi pancing dasar terhadap hasil tangkapan, dan mengidentifikasi jenis-jenis ikan yang tertangkap.

\section{METODOLOGI PENELITIAN}

Penelitian ini dilakukan di perairan Teluk Manado Sulawesi Utara pada bulan Juli - Oktober 2018, yang di kerjakan dengan mengikuti metode eksperimental. Teknik pengumpulan data dilakukan dengan cara mengoprasikan 8 unit alat tangkap pancing dasar, mengunakan umpan ikan layang (Decapterus sp), tongkol (Auxis rochii), cumi-cumi (Loligo $s p$ ) dan teri (Stolephorus sp) sebagai perlakuan. Pengoperasian pancing dasar dilakukan selama 4 kisaran waktu, yang bertindak sebagai kelompok dalam percobaan; yaitu jam 04:00 - 06:00, >06:00 - 08:00, 14:00 - 16:00, $>16: 00-18: 00$.

Analisis data untuk mendekati tujuan pertama, yaitu mempelajari pengaruh beberapa jenis umpan terhadap hasil tangkapan pancing dasar, digunakan model Rancangan Acak Kelompok (Steel and Torrie, 1989) dengan rumusan matematis sebagai berikut:

$$
\begin{aligned}
Y_{i j} & =\mu+\eta i+\beta j+\sum i j \\
i & =1,2, \ldots \ldots \ldots \ldots \mathrm{r} \text { (kelompok waktu operasi) } \\
j & =1,2, \ldots \ldots \ldots \ldots . \mathrm{t} \text { (perlakuan jenis umpan) }
\end{aligned}
$$

dimana:

$Y i j=$ Pengamatan pada seluruh satuan percobaan

$\mu=$ Rata-rata umum

$\eta i=$ Pengaruh kelompok ke $\mathrm{i}$

$\beta j=$ Pengaruh perlakuan ke $\mathrm{j}$

$\Sigma i j=$ Pengaruh kelompok ke $\mathrm{i}$ dan perlakuan ke $\mathrm{j}$.

Untuk memenuhi persyaratan analisa dalam menarik kesimpulan, maka dirumuskan hipotesa sebagai berikut: hipotesis dasar $H_{0}$ adalah $\eta=0$, (j $=1,2, \ldots \ldots . \mathrm{r})$, yang berarti secara statistik 
perbedaan jenis umpan pada pancing dasar memberikan pengaruh yang nyata terhadap hasil tangkapan. Sedangkan hipotesis tandingan $H_{l}$ adalah $\eta \neq 0,(j=1,2, \ldots \ldots . . \quad r)$, dimana secara statistik perbedaan jam operasi tidak berpengaruh nyata terhadap hasil tangkapan.

Hipotesis tersebut diuji dengan menggunakan uji $\mathrm{F}$ pada tabel analisis ragam dengan kriteria: Jika $\mathrm{F}_{\text {hitung }}<\mathrm{F}_{\text {tabel}}$, maka secara statistik terima $H_{0}$ dan tolak $H_{l}$, berarti hasil tangkapan berpengaru pada jenis umpan. Jika $F_{\text {hitung }}>F_{\text {tabel, maka secara }}$ statistik terima $H_{1}$ dan tolak $H_{0}$, berarti hasil tangkapan tidak berpengaru pada jam operasi.

Nilai $F$ tabel adalah nilai $F \alpha\left(v_{1}, v_{2}\right)$ yang diperoleh dari daftar distribusi $\mathrm{F}$ di mana $\alpha$ taraf uji yang digunakan $(0,01$ dan 0,05$), \mathrm{v}_{1}$ yakni derajat bebas $(\mathrm{db})$ pembilang $($ dari perlakuan $)=\mathrm{t}-1$, dan $\mathrm{v}_{2}$ yakni derajat bebas penyebut (dari galat $)=(\mathrm{r}-1)$ $(\mathrm{t}-1)$.

Jika penggunaan perlakuan berpengaruh, maka akan dilanjutkan dengan Uji Beda Nyata Terkecil (BNT), untuk mengetahui seberapa besar perbedaannya, dengan rumus:

BNT $(1 \%)=\mathrm{t}(\mathrm{db}$ acak, $1 \%) \times \mathrm{Sd}$.

Dimana, $S d=\sqrt{\frac{2 K T E}{n}}$

dimana,

BNT $(1 \%)=$ Beda nyata terkecil pada tingkat kepercayaan $1 \%$

$\mathrm{t}(\mathrm{db}$ acak, $1 \%)=$ Simpangan baku beda nilai tengah

KTE $=$ Kuadrat tengah acak

$S d \quad=$ Simpangan baku nilai tengah

$n \quad=$ Ulangan

Jenis-jenis ikan yang tertangkap di identifikasi berdasarkan buku petunjuk Allen (2000), dan Allen $d k k$. (2003). Jenis ikan yang sulit diidentifikasi di lapangan dipotret kemudian diawetkan dan diidentifikasi di laboratorium.

\section{HASIL DAN PEMBAHASAN}

\section{Hasil Tangkapan}

Hasil tangkapan yang diperoleh selama penelitian sebanyak 67 ekor; yang terdiri dari 5 spesies ikan. Sebaran hasil tangkapan berdasarkan perlakuan jenis umpan dan kelompok waktu operasi disajikan dalam Tabel 1.

Gambar 1 memperlihatkan bahwa umpan ikan layang memberikan hasil tangkapan yang terbanyak (32 ekor) kemudian diikuti berturut-turut oleh cumi-cumi (15 ekor), teri (11 ekor) dan tongkol ( 9 ekor).

Gambar 2 menunjukan bahwa tangkapan terbanyak terjadi pada pagi hari jam $04.00-06.00$ kemudian diikuti jam $>06.00-08.00$, dan sore hari sekitar jam $>16.00-18.00$.

\section{Hasil Analisis}

Sesuai dengan tujuan penelitian yang telah ditetapkan, maka analisis dengan model Rancangan Acak Kelompok Hasilnya bisa di lihat pada tabel 2. Hasil analisis sidik ragam (Tabel 2) menunjukkan bahwa $F_{\text {hitung }}>F_{\text {tabel}}$, pada taraf nyata $95 \%$ untuk perlakuan, sehingga secara statistik menerima hipotesis tandingan $\mathrm{H}_{1}$ dan menolak hipotesis dasar $\mathrm{H}_{0}$. Hal ini berarti bahwa perbedaan penggunaan beberapa jenis umpan sebagai perlakuan, berpengaruh nyata terhadap hasil tangkapan pancing dasar. Namun perbedaan kelompok waktu operasi (jam) berpengaruh tidak nyata terhadap hasil tangkapan. Untuk mengetahui perlakuan mana yang paling berpengaruh, maka dilanjutkan dengan uji Beda Nyata Terkecil (BNT). Langkah-langkah uji BNT untuk perlakuan disajikan dalam Tabel 3.

$$
\begin{aligned}
& B N T(0.01)=t(d b a c a k, 0.01) x S d \\
& \operatorname{dimana} S d=\sqrt{\frac{2 K T E}{n}}=\sqrt{\frac{24.0625}{4}}=1.425219 \\
& \text { t.01(db.9) }=3.25 \\
& \text { BNT }=3.25 \times 1.425219=4.63196
\end{aligned}
$$

\begin{tabular}{|c|c|c|c|c|c|c|}
\hline \multirow{2}{*}{$\begin{array}{l}\text { Kelompok waktu } \\
\text { Operasi }\end{array}$} & \multicolumn{4}{|c|}{ Perlakuan Umpan } & \multirow{2}{*}{ Total } & \multirow{2}{*}{ Rataan } \\
\hline & Layang & Cumi & Tongkol & Teri & & \\
\hline $04: 00-06: 00$ & 13 & 6 & 3 & 2 & 24 & 6 \\
\hline$>06: 00-08: 00$ & 9 & 4 & 2 & 3 & 18 & 4.5 \\
\hline $14: 00-16: 00$ & 3 & 2 & 2 & 3 & 10 & 2.5 \\
\hline$>16: 00-18: 00$ & 7 & 3 & 2 & 3 & 15 & 3.75 \\
\hline Total & 32 & 15 & 9 & 11 & 67 & \\
\hline Rataan & 8 & 3.75 & 2.25 & 2.75 & & \\
\hline
\end{tabular}

Tabel 1. Sebaran hasil tangkapan berdasarkan perlakuan dan kelompok 


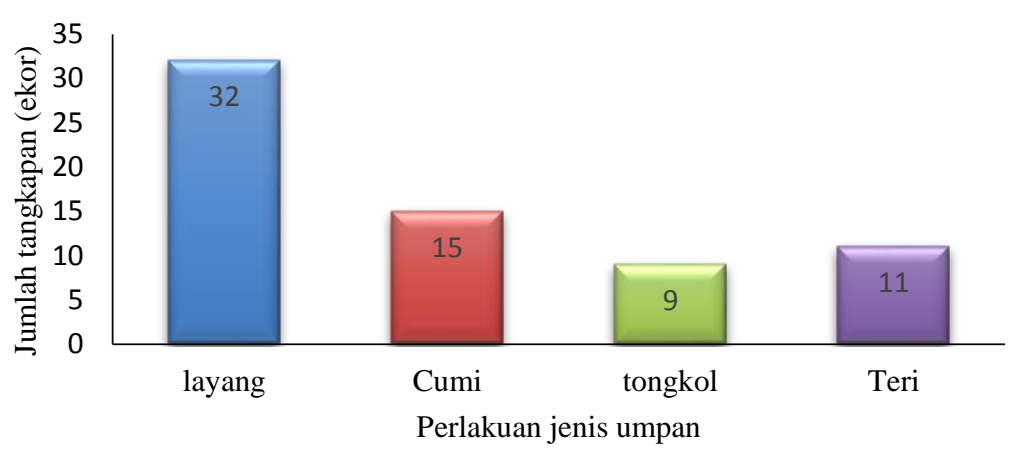

Gambar 1. Jumlah tangkapan berdasarkan perlakuan jenis umpan

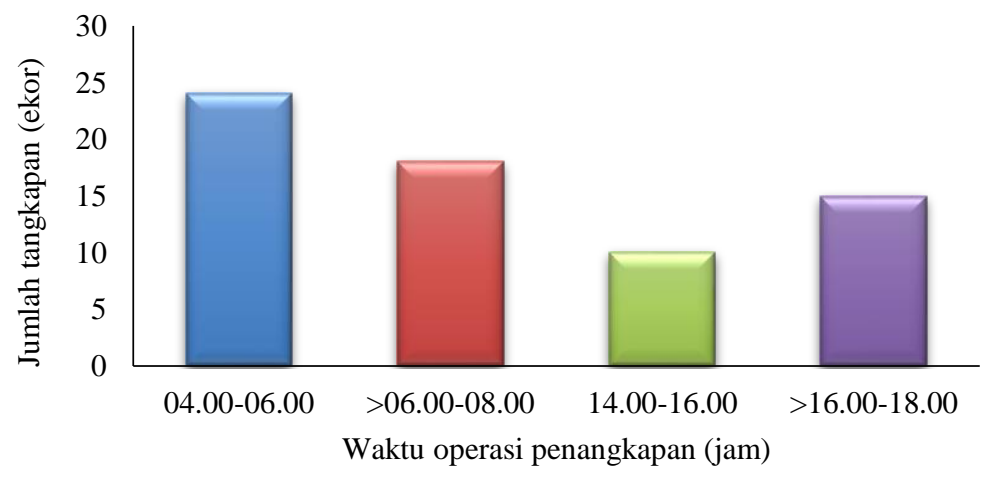

Gambar 2. Jumlah tangkapan berdasarkan kelompok waktu operasi

Tabel 2. Daftar analisis sidik ragam

\begin{tabular}{lllllll}
\hline $\begin{array}{l}\text { Sumber } \\
\text { Keragam }\end{array}$ & Db & \multirow{2}{*}{ JK } & KT & \multirow{2}{*}{ Fhit } & \multicolumn{2}{c}{ F tabel } \\
\hline Perlakuan & 3 & 82.1875 & 27.39583 & $6.74^{*}$ & 3.86 & 6.05 \\
Kelompok & 3 & 25.6875 & 8.5625 & $2.11 \mathrm{~ns}$ & 3.86 & 6.99 \\
Galat & 9 & 36.5625 & 4.0625 & & & \\
N. Tengah & 1 & 280.5625 & & & & \\
Total & 16 & 144.4375 & & & & \\
\hline
\end{tabular}

Keterangan: $*$ = berbeda nyata, $\mathrm{ns}=$ non significant

Tabel 3. Uji BNT untuk perlakuan

\begin{tabular}{lllll}
\hline Jenis umpan & N. tengah & Selisih & Nilai & Sig. \\
\hline Layang (L) & 8 & L-C & 4.25 & ns \\
Cumi (C) & 3.75 & L-T & 5.75 & $* *$ \\
Tongkol (T) & 2.25 & L-Tr & 5.25 & $* *$ \\
Teri (Tr) & 2.75 & C-T & 1.5 & ns \\
& & C-Tr & 1 & ns \\
& & T-Tr & -0.5 & ns \\
\hline
\end{tabular}

Keterangan: $*$ = berbeda nyata, $\mathrm{ns}=$ non significant

$\mathrm{L}=$ Layang, $\mathrm{C}=$ Cumi, $\mathrm{T}=$ Tongkol, $\mathrm{Tr}=$ Teri

$\begin{array}{llll}\text { Layang } & \text { Cumi } & \text { Tongkol } & \text { Teri }\end{array}$


Hasil uji BNT untuk perlakuan menunjukkan bahwa penggunaan umpan layang tidak berbeda nyata dengan umpan cumi, tetapi berbeda sangat nyata dengan umpan tongkol dan umpan teri. Penggunaan umpan cumi, tongkol dan teri tidak menunjukkan perbedaan yang nyata di antara ketiganya.

\section{Pembahasan}

Proses pengelompokan operasi penangkapan di lakukan secara acak oleh setiap para pemancing, jumlah perahu sebanyak 4 unit dengan jumlah orang sebanyak 8 orang karena dalam satu perahu masing-masing 2 orang, jumlah umpan yang di pakai sebanyak 4 jenis umpan, kelompok pertama mengunakan jenis umpan layang dan tongkol, sedangkan kelopok kedua mengunakan umpan cumi-cumi dan teri, kelompok ketiga mengunakan umpan tongkol dan cumi, ke empat mengunakan umpan teri dan layang jadi dalam beberapa kali experimental fhishing di lakukan sebanyak 4 kali.

Umpan yang baik dalam setiap operasi penangkapan harus mempunyai warna yang kontras dengan warna perairan di mana pancing tersebut di operasikan. Ikan mempunyai kemampuan untuk membedakan warna dan biasanya akan lebih tertarik pada objek yang mempunyai warna kontras atau putih mengkilap. Umpan merupakan salah satu faktor penting dalam menunjang keberhasilan suatu operasi penangkapan ikan, khususnya untuk alat tangkap pasif seperti pancing.

Jumlah total hasil tangkapan berdasarkan perlakuan umpan pada tabel 1 dan gambar 1 dan 2 menunjukan bahwa hasil tangkapan layang sebanyak 32 ekor, cumi 15 ekor, teri 11 ekor dan tongkol 9 ekor. Tingginya hasil tangkapan pada umpan layang dan umpan cumi, mungkin berkaitan dengan aroma kedua umpan tersebut yang tajam dan lebih tahan di dalam air, dibandingkan dengan jenis umpan lainnya karena umumnya ikan-ikan demersal lebih mengandalkan indera penciuman untuk mencari makanan.

Keberhasilan alat tangkap berumpan sangat ditentukan oleh aktifitas hidup mencari dan menangkap makanan, pengetahuan yang diperoleh melalui studi-studi tentang tingkah laku ikan mengambil makanan, akan sangat membantu untuk memahami interaksi spesies target dengan alat tangkap berumpan (Lokkeborg, 1994). Batas respon ikan target terhadap bau umpan (bait odour) juga ditentukan oleh besarnya active space dimana tingkah laku food-searching berlangsung.
Permasalahan pokok pada alat tangkap yang menggunakan umpan terletak pada pemahaman yang lebih baik tentang proses tertangkapnya biota laut dengan alat tangkap tersebut. Fokus utama untuk memahami proses tertangkapnya ikan ialah tertuju pada umpan yang merangsang ikan untuk makan; kemudian penglihatan dan penampilan fisik yang dapat menstimulasi respon positif atau negatif terhadap alat tangkap (Reppie, 2010).

Tingkah laku makan dari ikan diklasifikasikan oleh Atema (1971) ke dalam empat fase, yaitu: terangsang bau umpan (arousal), mencari posisinya (search location), mengambil makanan (food uptake), dan memasukan ke mulut atau menelannya (food ingestion). Hampir semua ikan menggunakan penciuman untuk mendeteksi jarak mangsa (Atema, 1980). Jarak dimana ikan dapat mendeteksi kehadiran umpan long line ditentukan oleh besarnya volume atraktan makanan yang dilepaskan dari umpan, dimana konsentrasinya di atas ambang chemosensori ikan (Wilson dan Bossert, 1963).

Pengoperasian pancing ikan dasar dilakukan sehari 2 kali yaitu pagi dan sore. Pagi hari dikelompokkan masing-masing pada pukul 04:00 06:00, >06:00 - 08:00 wita dan sore hari pada pukul 14:00 - 16:00, >16:00 - 18:00wita. Dalam hal ini menunjukan bahwa tangkapan terbanyak terjadi pada pagi hari jam 04:00 - 06:00 kemudian diikuti jam >06:00 - 08:00, dan sore hari sekitar jam $>$ 16:00 - 18:00. Hal ini diduga bahwa pada waktu tersebut ikan akan bergerak secara vertikal pada saat menjelang pagi hari dan sore hari.

Walaupun tidak dilakukan pengukuran kecepatan arus saat penelitian, tetapi pengamatan lapangan menunjukan bahwa ikan lebih aktif memakan umpan ketika kecepatan arus sedang. Menurut Ferno, et al. (1986), respon ikan terhadap umpan dipengaruhi baik oleh arus lemah maupun arus kuat. Pengamatan lapang tentang tingkah laku ikan whiting (Gadus merlangus) terhadap pancing berumpan, menunjukan bahwa aktivitas ikan lebih besar pada saat berarus daripada tidak berarus. Lebih banyak ikan tertarik pada umpan saat berarus karena stimuli olfactory terbawa lebih jauh. Namun terdapat sejumlah kecil ikan yang terkena respon yang tidak bereaksi karena mungkin lemahnya pedoman arah.

Menurut teori intermediate disturbance bahwa tingginya keanekaragaman biota karena kondisi yang tidak seimbang, dan jika tidak ada gangguan maka keanekaragamannya akan turun, keanekaragaman yang tertinggi terjadi apabila ada 
gangguan skala menengah, baik frekuensi maupun intensitasnya. Sebaliknya keanekaragaman terendah terjadi pada kondisi ekstrim, yaitu tidak ada gangguan sama sekali atau gangguan terlalu besar (Connell et al. 1998).

\section{KESIMPULAN}

Perbedaan penggunaan jenis umpan pada pancing dasar berpengaruh nyata terhadap hasil tangkapan, umpan yang terbaik adalah ikan layang kemudian diikuti oleh cumi-cumi. Perbedaan waktu operasi tidak berpengaru nyata terhadap hasil tangkapan, Waktu operasi yang terbaik adalah pagi hari (jam 04:00 - 06:00 ) dan diikuti sore hari (jam >16:00 18:00). Hasil tangkapan yang diperoleh selama penelitian sebanyak 67 ekor, yang terdiri dari 5 spesies ikan.

\section{Ucapan Terima Kasih}

Ucapan terima kasih kepada bapak Daud, Pony, Andi, Ape, Ating yang sudah membantu dalam proses penelitian dan sudah memberikan fasilitas dalam pelaksanaan penelitian.

\section{DAFTAR PUSTAKA}

Allen G. 2000. A field guide for anglers and diver. Marine Fishers of South-East Asia, 292 p. Peripus.

Allen G, Steene R, Human, Deloach C, 2003. Feef fish identifikasi tropikal pasifik, 484 p. Standard industri Ptd Singapura.

Atema J. 1971. Structures and functions of the senses of taste in the catfish (Ictalurus natalis). Brain Behav. Evol., 4, 273-94.

Atema J. 1980. Chemical senses, chemical signals and feeding behaviour in fishes. In: Fish behaviour and its use in the capture and culture of fishes. Pp. 57-101. ICLARM conf. Proc. 5 Manila.

Badrudin, M. 1998. Sumberdaya ikan demersal. Dalam: Potensi dan penyebaran sumberdaya ikan laut di perairan
Indonesia, Komisi nasional pengkajian stok sumberdaya ikan laut. 139-155

Connell, S.D, M.A Samoilys., M.P.L. Smith., J. Legata, 1998. Comparisons of abundance of corai-ref fish: Catch and effort suverys vs visual census. Autralian Jurnal of Ekology 23: 579-586.

Ferno A, Solemdal P, Tilseth S. 1986. Field studies on the behaviour of whiting (Gadus merlangus) toward baited hooks. Fisk Dir. Ser. Hav. Unders. 18,83-95.

Http:/www.dkp.go.id. 2008. Buku petunjuk teknis (Juknis) penangkapan ikan ramah lingkungan. DKP. 2 hal.

Janis U. E. Luasunaung A, dan Manoppo L 2016. Pengaruh ekstrak udang pada umpan terhadap hasil tangkapan pancing dasar di perairan Tateli Weru, Kabupaten Minahasa Jurnal Ilmu dan Teknologi Perikanan Tangkap 2(3): 126-129, Juni 2016 hal 126-129. ISSN 2337-4306

Lokkeborg S. 1994. Fish behaviour and long line. In: Marine fish behaviour in capture and abundance estimation, (9-27). Fishing News Books.

Onthoni.J.G, Manoppo L dan Pamikiran R. D. Ch, 2017. Pengaruh jenis umpan terhadap hasil tangkapan pancing dasar di perairan Marore Kecamatan Kepulauan Marore Kabupaten Kepulauan Sangihe, Jurnal Ilmu dan Teknologi Perikanan Tangkap 2(6): 217-222, Desember 2017 hal 217 222, ISSN 2337-4306

Ram, D. C. 1995. Dynamics of the deepwater snapper (Pristipomoides) resources in tropical Australia. Joint FFA/SPC Workshop on the management of South Pacific Inshore fisheries. Noumea. New Caledonia, 26 June-7 July 1995.

Reppie E. 2010. Pengaruh Minyak Cumi Pada Umpan Bubu Dasar Terhadap Hasil Tangkapan Ikan-Ikan Karang. Jurnal Perikanan dan Kelautan Tropis. Vol VI, No. 3. Desember 2010. ISSN 1411-9234 (140-143)

Senewe G. S. Kumajas H.J dan Pamikiran R. D. Ch 2019. Pengaruh jenis umpa terhadap hasil tangkapan pancing dasar di Pantai Desa Poopoh Jurnal Ilmu dan Teknologi Perikanan Tangkap 4(1): 16-21, Juni 2019 hal 16-21 pISSN 2337-4306 e-ISSN 2656 -906X

Suman, A. 2007. Hasil Penelitian Stok Sumberdaya Ikan Demersal Laut Dalam di Perairan ZEE Samudera Hindia Sebelah Selatan dan Barat Sumatera (Kerjasama Penelitian antara Pemerintah Indonesia dan Jepang)

Steel, R.G.D. and J.H. Torrie, 1989. Principles and procedures of statistics. Approach. 2nd ed. Mc Graw Hill International Book Company. London. 633 p.

Wilson EO, Bossert WH. 1963. Chemical communication among animals. Recent Prog. Hormone Res. 19, 673-716. 